Open Access

\title{
The new silk road and its potential for sustainable development: how open digital participation could make BRI a role model for sustainable businesses and markets
}

\author{
Peter Seele ${ }^{1 *}$, Christoph D. Jia ${ }^{2}$ and Dirk Helbing ${ }^{3,4,5}$
}

\footnotetext{
* Correspondence: peter.seele@usi.ch ${ }^{1}$ USI Lugano, Via Buffi 13, CH-6900

Lugano, Switzerland

Full list of author information is available at the end of the article
}

\begin{abstract}
China's New Silk Road (aka Belt and Road Initiative (BRI)) will invest a 1 trillion USD budget across Asia, Africa and Europe. As BRI wants to contribute also to sustainable development, the authors argue that only open digital participation of all citizens, corporations and governments and the collective intelligence, collaborative innovation and co-creation will make BRI a global role model for sustainability. For a highly networked, globalized, complex and digitalized world with limited resources the key ingredients for sustainable success are the following 10Cs: co-thinking, coworking, co-learning, co-creation, combinatorial innovation, co-ownership, coordination, co-operation, co-evolution, and collective intelligence. By linking BRI with digital infrastructures and corporate data management systems, a coordinated but distributed effort may be achieved with positive effects on social responsibility and sustainability for supply chains, data management, corporate reporting and regulatory issues.
\end{abstract}

Keywords: New silk road, Digital sustainability, Digital democracy, Social sustainability, Sustainable development

\section{Introduction}

The new silk road implies new geopolitics

A gigantic new Silk Road is under construction. The so-called Belt and Road Initiative (BRI) is currently underway, being one of the world's largest infrastructure projects for the years to come. The one trillion US dollar project was initiated by China and is meant to create a trade network comprising roads, railroads, harbors and airports. With this, geopolitics are about to change. The new Silk Road will connect Asia with Europe and parts of Africa through corridors, land bridges, maritime bridgeheads and a net of dedicated power plants. As the US pursues a protectionist approach and Europe is stuck in political uncertainty, the growing Chinese dominance is hard to overlook. BRI certainly goes beyond mere supply chain infrastructure and has a huge impact on geo-economic and geo-political implications on several players, particularly also on the European Union (Amighini 2018). President Xi Jinping's 3,5 h speech at the 19th Communist Party Congress left little doubt that China has high ambitions to take

(c) The Author(s). 2019 Open Access This article is distributed under the terms of the Creative Commons Attribution 4.0 International License (http://creativecommons.org/licenses/by/4.0/), which permits unrestricted use, distribution, and reproduction in any medium, provided you give appropriate credit to the original author(s) and the source, provide a link to the Creative Commons license, and indicate if changes were made. 
on more responsibility and assume leadership. As the original concept of BRI was driven by economic development, it became apparent for both, members of the Chinese authorities (Huadong 2018) as well as scholars (Li et al. 2015; Seele and Helbing 2018), that BRI offers perspectives of development also for sustainability - particularly with regard to digital technology. However, modern infrastructures is not enough to address today's planetary and societal challenges and solve humanity's problems: The questions of how to overcome our unsustainable lifestyles, social inequality and conflict, climate change and environmental harm are far from being solved. An answer has been attempted in the formulation of the Sustainable Development Goals (SDG) by the United Nations in the 2015 Paris Accords. A successful implementation of these goals, however, requires the activation and mobilization of the innovative potential of civil society globally. For BRI we hold that it is not only the central authority of the organizing government, but also the private sector, which may contribute to sustainable development (Welford 2018), in line with the SDGs and boosted by digital technology. This is not an easy task, as businesses act under adverse conditions facing dilemmas (Kolk and Lenfant 2018) to contribute to local development. Here we see great potential, if the BRI is managed and organized in a participatory way, dedicated to contributing to sustainable development. In this regard, Sun et al. (2018) have stressed the importance of 'good governance' for BRI. We may add, that otherwise, as claims to make BRI sustainable are manifold, BRI runs into the risk of being accused of greenwashing (Seele and Gatti 2015). Therefore the incentive to make BRI a rigorous contribution to sustainable development with governments and businesses joining forces is even more an imperative strategy.

\section{BRI and SDGs: A win-win?}

If we take the economic development perspective as intended by the BRI as a given - albeit at an early stage and far from being completed, facing several challenges (Tolipoy 2018) the development strategy of China's current leader Xi Jinping offers a welcome chance to elevate sustainable development and systemic resilience to a new level, coordinated across three continents, promising international trade and prosperity for many and for long. As infrastructure alone allows for synergies and economy-of-scale effects across the supply chain, this may be used to contribute to a more sustainable management. The potential to align the BRI and SDGs is promoted by many different actors involved in both BRI and SDGs, but is particularly championed by China's role to "lead on climate change" through the BRI, in order to "help the rising China begin a new era as a global leader in climate responsibility" (Wang and Wang 2017). As the former IMF managing director Michel Camdessus (2017) points out, the BRI offers a unique leadership opportunity for China to organize sustainable development along and within its corridors, land bridges and maritime bridgeheads. This has become particularly clear since the United States has decided to withdraw from the Paris Climate Accord (Trump 2017). At the same time other major players are still hesitant to join forces with the BRI. This is particularly true for highly industrialized countries as a McKinsey report points out: "Relations with Japan and the United States remain volatile, with the potential for damaging discontinuities in trade and investment" (Orr 2017). The endeavor of aligning the BRI and SDGs enjoys direct support from the UN secretary general, who sees an opportunity to "help countries make the 
transition to clean-energy, low-carbon pathways - instead of locking in unsustainable practices for decades to come" (UN News Center 2017). Also Huadong, professor at the "Chinese Academy of Sciences" in Beijing and president of the "International Society for Digital Earth" proposes steps towards the "Digital Silk Road" by sharing big data from satellite imagery to save sensitive environments that otherwise would be "lost and exposed to risk" (Huadong 2018, p. 26). Next to the environmental dimension, the authors also stress the possibility of the BRI to increase the contribution to sustainability by addressing social sustainability issues (Seele and Helbing 2018).

\section{Participatory digital platforms to improve the BRI}

How can this win-win scenario of the integration of sustainable development and the proposed interconnection of participating countries be brought about? We agree that the tremendous effort of developing the BRI creates exciting opportunities to invigorate the SDGs. This is particularly true for the potential of digitalization to promote sustainability. In sustainability research, digitalization has been described as "game changer" (Seele and Lock 2017), offering new possibilities to promote sustainability. Generally speaking, there are two pathways to unfold this game-changing potential: One is by centralized authoritarian digital intelligence as described in the theory of the "Digital Sustainability Panopticon" (Seele 2016), which is the approach currently applied by the BRI with a centralized authority and rigorous surveillance and social credit scores. This 'wise king' approach is juxtaposed by a more open democratic and participatory approach from computational social science (Mann and Helbing 2017), building on the diversity of "digital sustainability stakeholders" (Lock and Seele 2017) working hand in hand in producing, managing and analyzing big data. To build on this premise and to ensure that the BRI does indeed live up to its sustainability promise, we propose to add some ingredients.

Our guiding questions are:

- How could the BRI achieve the level of diversity needed to spur a diverse innovation ecosystem (Hidalgo et al. 2007), support social stability (Helbing 2013), wide-spread citizen participation, and combinatorial innovation (Mann and Helbing 2017)?

- How can as many countries as possible agree on the stewardship and crafting of the infrastructure (design and operation) of the BRI project, and work together towards the positive outcomes that it promises?

To address these questions, different approaches are possible and likely. It could be argued that a centralized authority would organize the (digital and other) infrastructure to invite for participation and development. A suitable architecture could certainly increase the efficiency and coordination of local and global decision making. One promising path that we would like to propose here is open participatory collaboration following the idea of the 'wisdom of crowds'. Decentralization and diversity play key roles in this collaborative design, which can also increase innovation and resilience, which both benefit sustainability. One crucial element to achieve the goals of economic, social and environmental sustainability and resilience is to consider the connectivity "physically, economically, socially, and digitally", as Honghui and Ting state (2016). Connectivity as a public good 
could be achieved along the lines of the BRI by incorporating "green finance and corporate social responsibility" into its mission (Honghui and Ting 2016).

To reach this ideal scenario and align the BRI with the SDGs, we propose a collaborative digital framework that can incorporate the full power of collective intelligence and its problem-solving capacity. We believe that, by combining several approaches and integrating different perspectives, collective intelligence can beat even the best isolated solutions (Page 2007), as collective intelligence is proven to create outcomes that are more resilient, sustainable and stakeholder oriented. Additionally, collective intelligence solutions may also produce higher levels of security, particularly as insurance and private security are among the key challenges of the BRI (Arduino 2018).

Such diversity depends on multiple players searching independently for solutions, which are then combined or integrated as good as possible (at least some of these solutions). This in turn has the advantage that, in case of one or several system components failing, other players can flexibly adapt to the challenge and act to (re)build an even more sustainable (digital) infrastructure in the spirit of anti-fragility (Taleb 2014) and systemic resilience. Predictive algorithms (Seele 2017) in addition could act as early stage indication to flag probable sustainability disasters, as an active risk management is a key ingredient to secure the New Silk Road (Zhou 2018).

In addition, by building on deliberative independent participatory platforms in an ever-growing interconnected and digitized civil society, the BRI would probably receive more whole-hearted support from Europe and the US, who currently do not appear to be truly committed, as Michael Clauss (2017), among others, points out. This lack of interest could clearly be witnessed by the absence of high-level Western political operatives at the BRI meeting in early 2018.

To connect the knowledge, ideas, and demands of shareholders and stakeholders, to provide locally and culturally tailored services to them, and to benefit from the power of crowd sourcing and collective intelligence, an open, decentralized communication and deliberation platform for the BRI could be created by combining and extending participatory platforms such as UN OCHA, Global Pulse, the Deliberatorium, and Nervousnet (see nervousnet.info). A similar approach can be found in the FuturICT initiative (see www.futurict.eu, www.futurict2.eu) or the concept of "sustainable digital artefacts" in the light of open source and access (Stuermer et al. 2016). FuturICT aims to generate crowd-sourced data, using smartphones and other Internet of Things sensors run by many engaged participants from both, civil society and governmental institutions. The wisdom of the many has the advantage that risks are also distributed, in contrast to a classical control center approach. Mitigated risk is one of the key features of the BRI, as Tang (2018) pointed out. Therefore, the distributed networks of open digital participation in return are directly linked with the promotion of sustainability and could be used also for the prevention of conflict and the overall promotion of peace - a key ingredient for a sustainable world (Helbing and Seele 2017). To mobilize the potential of civil society, e.g. ideas, talents and engagement, particularly also in areas which political governance and business investments do not reach, bottom-up participation is considered a key ingredient to boost sustainability and resilience. For example, "City Olympics" (Helbing 2017) could be a novel instrument to mobilize the potential of civil society, where various stakeholders contribute to developing new solutions to global problems in a way that combines competition and cooperation within a global network of cities. 
Conclusion: Resilience in a highly networked, globalized, complex, digital world: the 10 C's In conclusion, we stress the considerable limitations of a purely top-down governance system, which could not reach the level of responsible innovation (van den Hoven et al. 2013) and sustainability that would be achieved by the participatory mechanisms described above. Instead, it would result in a project that risks failure because of its inability to take root in the participating countries and civil societies and to respond to newly emerging technologies.

We argue that it is the civil society, i.e. the people who work and live, consume and pay taxes to their governments, who should be able to contribute to and co-create the new, sustainable world of the gigantic Silk Road project. This would add also to social sustainability and social justice, identified as a key driver of the BRI, which is thus far underrepresented (Seele and Helbing 2018). A similar argument applies to other transnational initiatives such as TPP, TTIP, CETA, TISA, the Agendas 21 and 2030, as well as many smart city, smart nation, and smarter planet projects recently proposed. The overall mandate of the United Nations should, therefore, be revisited in favor of a digital and more open, participatory perspective: In today's unsustainable world, we need resilient systems and organization. Resilience is increased by diversity, decentralization, and subsidiarity. Sustainability is improved by more awareness and opportunities to create feedbacks incentivizing a circular and sharing economy. All in all, to accomplish the transformation to a resilient and sustainable world, more participatory opportunities are needed. To turn the new Silk Road into a great economic, social, and environmental success story for all involved, in a highly networked, globalized, complex world with limited resources, the key ingredients for success are the following 10Cs:

1. co-thinking (to identify the challenges and prospects of the BRI),

2. co-working (to achieve synergy effects in distributed teams),

3. co-learning (to adapt what worked in one place to another place),

4. co-creation (to create added value, developed together across the BRI),

5. combinatorial innovation (to combine existing solutions in new ways),

6. co-ownership (of public infrastructures, goods, services and data, to promote fairness and prevent new kinds of colonialism),

7. co-ordination (to harmonize local and global initiatives),

8. co-operation (to overcome the limitations of a purely competitive economy and society),

9. co-evolution (to mutually catalyze activities and reach sufficient coherence and integration), and

10. collective intelligence (to enable the wisdom of crowds effect).

Even if the (normative) claims of decentralised participatory digital platforms are politically opportune and feasible, it remains an open question whether or not political will and international consensus emerges that would make the New Silk Road contribute to all three dimensions of sustainability (economic, environmental, and social). Currently, the lack of social responsibility and sustainability of this planet's management implies a risk of dangerous cascading effects and conflicts, which are a threat to all countries. This needs to be changed. 


\section{Abbreviations}

BRI: Belt and Road Initiative; CETA: Comprehensive Economic and Trade Agreement; IMF: International Monetary Fund; SDG: Sustainable Development Goals; TISA: Trade in Services Agreement; TPP: Trans-Pacific Partnership Agreement; TTIP: Transatlantic Trade and Investment Partnership; UN OCHA: United Nations Office for the Coordination of Humanitarian Affairs

\section{Acknowledgements}

Not applicable.

\section{Funding}

No funding was obtained by any of the authors for this publication.

\section{Availability of data and materials}

Data sharing not applicable to this article as no datasets were generated or analysed during the current study.

\section{Authors' contributions}

PS developed the original idea of the article and substantially engaged in the write up of the article. CDJ contributed particularly with the knowledge of China and how to address the issue of digital participation for the case of China. CDJ also substantially engaged in the write up of the article. DH contributed the specific solutions of digital participation and substantially engaged in the write up of the article. All authors read and approved the final manuscript.

\section{Competing interests}

The authors declare that they have no competing interests.

\section{Publisher's Note}

Springer Nature remains neutral with regard to jurisdictional claims in published maps and institutional affiliations.

\section{Author details}

'USI Lugano, Via Buffi 13, CH-6900 Lugano, Switzerland. ² Linya International Strategic Foresight, 244 Liaoning Road, Shanghai 200080, China. ${ }^{3}$ ETH Zurich, Clausiusstr. 50, CH-8092 Zurich, Switzerland. ${ }^{4}$ Complexity Science Hub Vienna, Wien, Austria. ${ }^{5}$ Technical University Delft, Delft, Netherlands.

Received: 26 September 2018 Accepted: 9 December 2018

Published online: 07 January 2019

\section{References}

Amighini A (2018) Beyond ports and transport infrastructure: the geo-economic impact of the BRI on the European Union. In: Arduino A, Xue G (eds) Securing the belt and road initiative. Palgrave, Singapore

Arduino A (2018) China's belt and road security: the increasing role of insurance and private security companies. In: Arduino A, Xue G (eds) Securing the belt and road initiative. Palgrave, Singapore

Camdessus M (2017) Why China's Belt and Road must be a pathway to sustainable development. In: South China Morning Post. http://www.scmp.com/comment/insight-opinion/article/2094611/why-chinas-belt-and-road-must-be-pathwaysustainable. Accessed 6 Nov 2017

Clauss M (2017) Why Europe and the US cannot afford to ignore China's Belt and Road. In: South China Morning Post. http:// www.scmp.com/comment/insight-opinion/article/2098527/why-europe-and-us-cannot-afford-ignore-chinas-belt-androad. Accessed 6 Nov 2017

Helbing D (2013) Globally networked risks and how to respond. Nature 497:51-59. https://doi.org/10.1038/nature12047

Helbing D (2017) City Olympics to improve the world. In: FuturlCT Blog. http://futurict.blogspot.com/2017/06/city-olympicsto-improve-world.html. Accessed 25 Nov 2018

Helbing D, Seele P (2017) Sustainable development: turn war rooms into peace rooms. Nature 549:458. https://doi.org/10. $1038 / 549458 \mathrm{C}$

Hidalgo CA, Klinger B, Barabasi A-L, Hausmann R (2007) The product space conditions the development of nations. Science 317:482-487. https://doi.org/10.1126/science.1144581

Honghui C, Ting G (2016) Building a shared vision for the belt and road initiative and the sustainable development goals. In: UNDP, CCIE, 2016 high-level policy forum on global governance. Scoping paper 2, Beijing

Huadong G (2018) Steps to the digital silk road. Nature 554:25-27. https://doi.org/10.1038/d41586-018-01303-y

Kolk A, Lenfant F (2018) Responsible business under adverse conditions: dilemmas regarding company contributions to local development. Bus Strateg Dev 1:8-16. https://doi.org/10.1002/bsd2.5

Li P, Qian H, Howard KWF, Wu J (2015) Building a new and sustainable "silk road economic belt". Environ Earth Sci 74:72677270. https://doi.org/10.1007/s12665-015-4739-2

Lock I, Seele P (2017) Theorizing stakeholders of sustainability in the digital age. Sustain Sci 12:235-245. https://doi.org/10 1007/s11625-016-0404-2

Mann RP, Helbing D (2017) Optimal incentives for collective intelligence. Proc Natl Acad Sci U S A 114:5077-5082. https://doi. org/10.1073/pnas.1618722114

Orr G (2017) What can we expect in China in 2018? In: McKinsey \& Company. https://www.mckinsey.com/global-themes/ china/what-can-we-expect-in-china-in-2018. Accessed 22 Feb 2018

Page SE (2007) The difference: how the power of diversity creates better groups, firms, schools, and societies. In: Princeton University press. Princeton, New Jersey 
Seele P (2016) Envisioning the digital sustainability panopticon: a thought experiment of how big data may help advancing sustainability in the digital age. Sustain Sci 11:845-854. https://doi.org/10.1007/s11625-016-0381-5

Seele P (2017) Predictive sustainability control: a review assessing the potential to transfer big data driven "predictive policing" to corporate sustainability management. J Clean Prod 153:673-686. https://doi.org/10.1016/j.jclepro.2016.10.175

Seele P, Gatti L (2015) Greenwashing revisited: in search of a typology and accusation-based definition incorporating legitimacy strategies. Bus Strateg Environ 26:239-252. https://doi.org/10.1002/bse.1912

Seele P, Helbing D (2018) Boost sustainability through social justice in China's belt and road initiative. Nature 555:311-311. https://doi.org/10.1038/d41586-018-03051-5

Seele P, Lock I (2017) The game-changing potential of digitalization for sustainability: possibilities, perils, and pathways. Sustain Sci 12:183-185. https://doi.org/10.1007/s11625-017-0426-4

Stuermer M, Abu-Tayeh G, Myrach T (2016) Digital sustainability: basic conditions for sustainable digital artifacts and their ecosystems. Sustain Sci 12:247-262. https://doi.org/10.1007/s11625-016-0412-2

Sun H, Tariq G, Kong Y, Khan MS, Geng Y (2018) Nexus between environmental infrastructure and transnational cluster in one belt one road countries: role of governance. Bus Strateg Dev 1:17-30. https://doi.org/10.1002/bsd2.6

Taleb NN (2014) Antifragile: things that gain from disorder, Reprint edn. Random House Trade Paperbacks, New York, NY

Tang Z (2018) CSR as a tool to mitigate risk for the B\&R Initiative: the case of Thailand. In: Arduino A, Xue G (eds) Securing the belt and road initiative. Palgrave, Singapore

Tolipoy F (2018) One belt, one road in Central Asia: Progress, challenges, and implications. In: Arduino A, Xue G (eds) Securing the belt and road initiative. Palgrave, Singapore

Trump D (2017) Statement by President Trump on the Paris climate accord. In: White House Off. Press Secr. https://www. whitehouse.gov/the-press-office/2017/06/01/statement-president-trump-paris-climate-accord. Accessed 4 Oct 2017

UN News Center (2017) At China's Belt and Road Forum, UN chief Guterres stresses shared development goals. In: Sustainable Development Goals. http://www.un.org/sustainabledevelopment/blog/2017/05/at-chinas-belt-and-roadforum-un-chief-guterres-stresses-shared-development-goals/. Accessed 6 Nov 2017

Van den Hoven J, Jacob K, Nielsen L, Roure F, Rudze L, Stilgoe J, Blind K, Guske AL, Riera CM (2013) Options for strengthening responsible research and innovation: Report of the expert group on the state of art in Europe on responsible research and innovation. European Commission, Brussels, Belgium

Wang C, Wang F (2017) China can lead on climate change. Science 357:764. https://doi.org/10.1126/science.aao2785

Welford R (2018) Editorial: the launch of a new journal, business strategy and development. Bus Strateg Dev 1:4-5. https:// doi.org/10.1002/bsd2.8

Zhou HM (2018) China, securing "belt and road initiative": risk management. In: Arduino A, Xue G (eds) Securing the belt and road initiative. Palgrave, Singapore

\section{Submit your manuscript to a SpringerOpen ${ }^{\circ}$ journal and benefit from:}

- Convenient online submission

- Rigorous peer review

- Open access: articles freely available online

High visibility within the field

- Retaining the copyright to your article

Submit your next manuscript at $\boldsymbol{\nabla}$ springeropen.com 